\title{
International Military Operations in the 21st Century. Global trends and the future of intervention
}

\section{Per M. Norheim-Martinsen og Tore Nyhamar (red.) New York: Routledge, Cass Military Studies, 2015}

Anmeldt av Anders Kjølberg*, Magister. Pensjonert forsker, tilknyttet Krigsskolen

Det er ikke daglig kost at en norsk bok om sikkerhetspolitikk blir utgitt på et stort internasjonalt forlag, derfor er det verd å merke seg at International Military Operations in the 21st Century. Global trends and the future of intervention, redigert av Per Martin Norheim-Martinsen og Tore Nyhamar nå er utgitt av Routledge, i serien Cass Military Studies. Boken er et resultat av det mangeårige arbeidet på Forsvarets forskningsinstitutt om internasjonale operasjoner, og den norske deltakelse i slike. De fleste forfatterne er, eller har vært, knyttet til dette miljøet. I tillegg har de toppet laget med to solide internasjonale eksperter på området, Robert Egnell fra Sverige, og David Ucko fra Storbritannia. La det være sagt med en gang: dette er en meget nyttig bok for alle som ønsker å forstå hvilke utfordringer en stat, og særlig en småstat som Norge, står overfor når den sender mannskaper til internasjonale militære operasjoner.

Dette har vært et prosjekt som har tatt tid, og resultatet er en gjennomarbeidet bok hvor de forskjellige kapitlene henger godt sammen, fordi det er de samme militære utfordringene som diskuteres gjennom alle kapitlene. Sluttproduktet er derfor noe langt mer enn en antologi. Det har i langt større grad blitt et samlet hele.

Forfatterne diskuterer et bredt spektrum av oppgaver og utfordringer i forbindelse med deltagelse i internasjonale operasjoner. De to redaktørene legger føringer for de følgende kapitlene hvor Per Martin Norheim Martinsen først diskuterer et antall globale trender av samfunnsmessig, økonomisk og teknologisk karakter, som vil kunne prege det internasjonale miljø som fremtidige militære operasjoner vil foregå i. Med basis i dette presenterer han ulike former for fremtidige internasjonale operasjoner. I tillegg til «tradisjonelle» operasjoner som høy-intensitetsoperasjoner, opprørsbekjempelse, militær støtte og rådgivning, spesialstyrkeoperasjoner og FN-operasjoner, diskuterer han også det han kaller «completely new mission types», som urbane operasjoner,

^Korrespondanse: Anders Kjølberg. Email: anders.kjolberg@gmail.com 
transnasjonale operasjoner, cyber-operasjoner, og operasjoner for å beskytte sivile. Disse operasjonstypene blir så analysert videre i hvert sitt kapittel, men før dette presenterer Tore Nyhamar et sett parametre som kan anvendes for å analysere disse operasjonene. Disse parametrene er «mandate», «consent», «conflict intensity», «operational environment» og «relative force composition and strength». Dermed knyttes de ulike kapitlene sammen til et hele.

Sverre Diesen presenterer i sitt kapittel «Future high-intensity conflict out of area» en mulig operasjon mot et regime i Afrika. Gitt de mange forskjellige utfordringene som genereres fra enkelte områder i dagens Afrika er dette et plausibelt scenario. Han trekker her inn begrepet "counter-regime» eller "CORE-operations», men uten å drøfte det nærmere, noe han kanskje burde ha siden dette begrepet vel fremdeles er ukjent for et engelsk-språklig publikum. Dette begrepsapparatet, som jeg lanserte for noen år siden, brukes vel først og fremst i Norge. Disse begrepene drøftes nærmere i Norge $i$ internasjonale operasjoner, (Heier \& Kjølberg red. 2015).

De øvrige kapitlene drøfter ulike typer deltagelse og forskjellige former for internasjonale militære operasjoner. Det vil føre for langt å komme inn på alle disse, til dels meget solide, innleggene i noen detalj. Guro Liens kapittel «Military advising and assistance operations» og Iver Johansens «Special operations forces - a weapon of choice for future operations?», tar begge som utgangspunkt at krympende budsjetter og færre mannskaper gjør at styrkeleverandører ser etter mindre ressurskrevende og mer kortvarige former for innsats. Militær rådgivning og bruk av spesialstyrker fremstår i denne forbindelse som aktuelle alternativer for ressurssterke småstater som Norge. Lokale styrker får da i langt større grad ansvaret for egen sikkerhet, og det utenlandske nærværet blir mindre synlig og derfor også mindre politisk krevende både for den lokale regjering og for innsatslandet.

Stian Kjeksrud diskuterer i sitt kapittel «The future of UN peacekeeping operations» de endringer man ser i karakteren av operasjoner i FN-regi. Han forventer mer «robuste» mandater, mindre vekt på stats- og nasjonsbygging, og større vekt på operasjoner med mer kortsiktig perspektiv, som stabilisering i en pågående konflikt og beskyttelse av sivile. Dette fører også til at FN-styrker i større grad vil ta parti i en konflikt. Mannskapene vil stort sett komme fra asiatiske og afrikanske land, men i noen grad supplert med nisjekapasiteter fra et begrenset antall europeiske mannskaper utstyrt med moderne teknologi.

En annen utvikling som kan påvirke karakteren av internasjonale militære operasjoner er det faktum at en stadig større del av befolkningen i aktuelle innsatsområder vil befinne seg i storbyer, og at kamphandlingene derfor ofte vil finne sted i «storbyjungelen». Konsekvensene av dette diskuteres av Per Martin NorheimMartinsen i kapitlet «The new urban operations». Her vil det bli langt vanskeligere å unngå sivile tap, med de konsekvenser dette har. Doktriner, trening og utstyr må også tilpasses denne virkelighet. Dette medfører store utfordringer, og hever trolig terskelen for at vestlige land involverer seg i slike operasjoner.

Konflikter blir også mer internasjonale, noe som medfører ulike former for utfordringer i forbindelse med internasjonale operasjoner. Dette er et problem Tore Nyhamar drøfter i sitt kapittel «Transnational operations». Det blir både flere aktører å 
forholde seg til og juridiske problemer å håndtere. «Safe heavens» og grensekontroll er gamle problemer, mens moderne informasjons- og kommunikasjonsteknologi skaper stadig nye. Problemene som oppstår er både av operativ, politisk og juridisk karakter.

Cyberkrigføring vil kunne bli et viktig virkemiddel i fremtidige internasjonale operasjoner, noe som drøftes av Siw Tynes Johnsen. Dette er et virkemiddel som kan påvirke både en motparts vilje og evne i en konflikt, for eksempel gjennom å påvirke holdninger og å redusere effektiviteten til en motparts våpensystemer.

Beskyttelse av sivile er en viktig legitimerende faktor ved iverksettelse av internasjonale operasjoner, men også en kontroversiell faktor. Problemstillingene i forbindelse med dette drøftes av Alexander Beadle i hans kapittel «Protection of civilians as a new objective in military operations». Sivile vil alltid rammes i krig, enten som en bivirkning av krigshandlingene eller fordi det kan være et mål i seg selv å ramme sivile. På samme måte kan beskyttelse av sivile være den primære årsak til en operasjon, eller det å hindre at sivilbefolkningen blir rammet av krigshandlinger kan være viktig for at en operasjon skal oppnå tilstrekkelig legitimitet både i de land som deltar $i$ en operasjon og i innsatslandet.

I tillegg til problemer på det operative plan er beskyttelse av sivile og et kontroversielt politisk problem. Dette gjelder spesielt i situasjoner hvor det er et regime og ikke en opprørsbevegelse det skal gripes inn mot. En slik inngripen representerer et alvorlig inngrep $i$ et annet lands indre anliggender, noe som er et brudd på et sentralt internasjonalt prinsipp og dermed forutsetter tung legitimitet, fortrinnsvis fra FNs sikkerhetsråd.

Dette understreker det mer generelle spørsmål mange vil stille seg når en slik bok kommer: hvilken relevans tidligere erfaringer og mulige fremtidige utfordringer $i$ forbindelse med internasjonale operasjoner har i dag, i så vel Norge som i den øvrige verden? Etter Irak, og ikke minst Afghanistan, er det få lands regjeringer som er spesielt lystne på nye internasjonale engasjementer «out of area». Dette er en holdning som trolig i enda større grad preger de militære etablissementer. Begge parter vil gjerne ha NATO «hjem» for å konsentrere seg om den type konflikt man ønsker å planlegge for; en konvensjonell storkonflikt. Erfaring viser både at internasjonale operasjoner som oftest kommer overraskende, og at slike operasjoner stadig endrer karakter. Det er derfor sannsynlig at Norge igjen vil bli involvert $i$ internasjonale militære operasjoner i det nærmeste tiåret, men også at erfaringer fra tidligere operasjoner bare i liten grad vil være overførbare til disse, fordi operasjonene har så ulik karakter. Det kan også argumenteres for at internasjonale operasjoner er "war of choice» og at siden norske interesser sjelden er direkte rammet av konflikter i de aktuelle innsatsområdene, behøver ikke Norge å delta. Men både deltagelse og ikke-deltagelse har sin pris og det er ikke alltid mulig å vurdere slike kostnader i forveien.

Vi må derfor ha i bakhodet at vi med stor sannsynlighet vil bli trukket inn i nye internasjonale operasjoner, men at vi ikke vet når, hvor og hvordan. Vi kan derfor ikke forutse det som kommer til å skje, men må ha tanker om hvordan man skal håndtere usikkerhet på dette området. 
Kapitlet, «Counterinsurgency operations revisited», av Robert Egnell og David Ucko, er etter denne anmelderens mening, bokens viktigste. Årsaken til dette er at det reiser sentrale overordnede problemstillinger på en måte som peker framover, og som har konsekvenser for hvordan vi bør tenke omkring hvordan vi kan forholde oss til og forberede oss på deltagelse $\mathrm{i}$ internasjonale operasjoner $\mathrm{i}$ fremtiden. Jeg vil derfor omtale dette kapitlet til slutt.

Egnell og Ucko presenterer noen av de utfordringene den vestlige verden har stått overfor i slike operasjoner og vanskelighetene med å møte disse. Et sentralt problem har vært at ambisjonene har vokst fra bare å ville skape stabilitet, til også å fremme demokrati, økonomisk utvikling og respekt for menneskerettigheter, dels ut fra den tanke at det bare er utvikling på disse områdene som kan skape langsiktig stabilitet. Dette er prisverdige ambisjoner, men samtidig er sammenhengen mellom militær maktbruk og politisk virkning langt fra klar.

Forfatterne stiller spørsmål om COIN-operasjoner, slik vi har sett dem, er liv laga i fremtiden. De har vist seg å være svært kostbare: politisk, finansielt og i form av tapte menneskeliv. Det er derfor et naturlig behov for å lete etter alternativer som er billigere på alle områder, mindre risikofylt, og ikke minst mer «effektive». Spørsmålet er om slike alternativer finnes!

Som de sier vil ingen «ved sine fulle fem» gå inn i operasjoner som de i Afghanistan og Irak igjen, men understreker meget riktig at ingen hadde forutsett hvordan disse operasjonene ville utvikle seg. De begynte begge som tilsynelatende vellykkede operasjoner mot et regime, ikke et opprør, men utviklet seg til en COIN-operasjon etter at regimene var fjernet. Slike situasjoner kan skapes også som et resultat av nye «vellykkede» operasjoner.

Egnell og Ucko diskuterer tre ulike typer operasjoner som kan være «billigere» og samtidig mer effektive. Det er «Libya-modellen», «indirect approach» og støtte til regionale og internasjonale organisasjoner. Libya-modellen, med hovedvekt på «death from above», viste seg effektiv for å bekjempe et regime, dvs at den kan være et mulig alternativ i CORE-operasjoner, men å fjerne et regime kan skape flere problemer enn det løser. Om den er egnet til å bekjempe et opprør er langt mer tvilsomt, fordi opprørsbevegelser i mindre grad har klart etablerte «tyngdepunkt». Støtte til regionale organisasjoner, som i Afrika, kan også vise til blandede resultater, også her avhengig av evnen og vilje til de som blir støttet. Man kan likevel være enige med forfatterne at dette er de mest aktuelle alternativene, men i hvilken grad de er effektive, og ikke bare billige, er et åpent spørsmål.

Selv om terskelen for inngripen nå er høy, kan det lett skapes situasjoner hvor ikke-inngripen er et enda større onde. Internasjonale operasjoner, på en eller annen måte, vil igjen kunne bli aktuelle, og Norge vil kunne bli bedt om å delta. Å kalle internasjonale operasjoner "wars of choice» kan vise seg å være en sannhet med modifikasjoner, fordi et «nei» kan ha negative sikkerhetspolitiske effekter. Selv om internasjonale operasjoner nå ikke blir prioritert i det militære system kan det være farlig å tro at deltagelse i slike operasjoner er noe som hører fortiden til. Kunnskap om internasjonale operasjoner bør derfor ikke forsvinne, selv om den nå lett kan forvitre. Som de sier bør den intellektuelle beredskap når det gjelder å håndtere ulike 
scenarier opprettholdes, ikke minst fordi prinsippene som ligger til grunn for konvensjonell krigføring bare i svært begrenset grad er relevant for internasjonale operasjoner. Det er vanskelig og farlig å måtte lære alt på nytt gjennom prøving og feiling. Derfor er denne boken nyttig å ha i bokhyllen, slik at den kan tas fram dersom man igjen blir stilt overfor slike utfordringer.

\section{Referanser}

Heier, Tormod, Anders Kjølberg \& Carsten F. Rønnfeld (red.) (2015) Norge i internasjonale operasjoner. Oslo: Universitetsforlaget (247-256). 